\title{
Effect of Surfactants on Foliar Wettability in Rice Plants
}

\author{
Gen-ichi Kadota and Shooichi Matsunaka \\ The Graduate School of Science and Technology, \\ Kobe University, Nada-ku, Kobe 657, Japan
}

(Received May 6, 1986)

\begin{abstract}
Foliar wettability of rice plants for aqueous solutions of nonionic surfactants was studied and compared with that of cabbage and soybean plants. Rice leaves were found highly water-repellent having large contact angles over $130^{\circ}$ and their wettability was affected by the addition of surfactants most among all the plants examined. The effectiveness of surfactants in enhancing retention of dye solutions in leaves was related to their effectiveness in decreasing surface tension. The surfactants gave the highest retention at their optimum concentrations, which appeared to correspond to their critical micelle concentrations; POE lauryl ether at $0.01 \%$, POE nonylphenyl ether at $0.1 \%$ and POE sorbitan monolaurate at 0.5 to $1.0 \% \mathrm{w} / \mathrm{v}$. It is therefore suggested that rice plants belong to the species with lower wettability and that they need wetting agents to improve foliar wettability.
\end{abstract}

\section{INTRODUCTION}

Before penetration into plant cuticles, spray droplets of any applied chemicals must be retained on the plant surface. The wettability of cuticular surface is considered to be one of the most important factors in prepenetration processes. ${ }^{1)}$ Factors affecting the wettability have been discussed mainly from two aspects; the properties of cuticular surface and physical properties of spray formulation. ${ }^{2)}$

Surface waxes, including both embedded within the cuticles and projecting from them, markedly influence foliar wettability. The epicuticular wax covering the cuticular surface varies in wettability among plant species. According to Holloway, ${ }^{1)}$ leaf surfaces can be roughly divided into two groups; those with contact angles below $90^{\circ}$ and those above $90^{\circ}$. The former are wettable and the latter difficult to wet. Contact angles over $110^{\circ}$ signify the presence of additional factors (roughness, leaf hairs) which are capable of modifying the hydrophobic properties of the surface. In addition, the high water-re- pellency of leaves is often due to wax projections producing the large contact angles of about $130^{\circ}$ to $160^{\circ} .^{3)}$

Wettability is also affected by physical properties of a spray formulation. ${ }^{4}$ Plant species can be divided into two opposite groups depending on how lowering the surface tension (ST) affects. ${ }^{2)}$ In one group lowering ST enhances retention ${ }^{5-7)}$ and in the other it reduces retention. ${ }^{8,9)}$

In this paper we describe the effect of surfactants on leaf wettability using rice plants as a standard of comparison with other plant species. No detailed information is available on the wettability of rice leaves with the microscopically rough surface. Difference in wettability among plant species is discussed in relation to the surfactant effect in aqueous formulation.

\section{MATERIALS AND METHODS}

\section{Test Plants}

Rice (Oryza sativa L., cv. Nakateshinsenbon), cabbage (Brassica olevacea L. var. capitata L., cv. Shikidorikanran) and soybean (Glycine max 
MERr., cv. Tamahomare) were used in this study. Five days after germination at $30^{\circ} \mathrm{C}$, rice plants were planted in plastic pots containing paddy soil treated with a fertilizer at a recommended rate and raised in a greenhouse. Cabbage and soybean were sowed in pots containing upland soil treated with the same fertilizer for basal dressing and also raised in the greenhouse.

All test plants were subjected to the following experiments at 7 to 8-leaf stage ( 7 to 8trifoliate stage in soybean).

\section{Surfactants and Commercial Pesticide Formulations}

Surfactants examined were all nonionic belonging to different groups (Table 1). Pesticides used for the retention study were emulsifiable concentrate formulations of IBP $(48 \%$, Kumiai Chemical Industry Co., Ltd.), carbaryl, MTMC (15 and 30\%, respectively, Nissan Chemical Co., Ltd.), diazinon (40\%, Tomono Nohyaku Co., Ltd.), isoprothiolane, phenthoate $(40$ and $50 \%$, respectively, Nihon Nohyaku Co., Ltd.), fenitrothion (50\%, Takeda Chemical Ind., Ltd.), and wettable powders of iprodione $(50 \%$, Nissan Chemical Co., Ltd.). They were all diluted to the level recommended for rice in field.

\section{Surface Tension and Contact Angle Measure- ments}

Surface tension of test solutions was determined at a given concentration with the aid of Du Noüy tensionmeter at $20^{\circ} \mathrm{C}$. All readings are uncorrected and represent apparent surface tension in dyne $/ \mathrm{cm}$.

In this experiment, the critical micelle concentrations (CMC) of surfactants were determined based on the relationship between ST and concentrations of the surfactant solutions. The maximum level for ST reduction was determined as CMC.

Contact angles were measured on photographs of droplet profiles. Two- $\mu \mathrm{l}$ droplets containing a surfactant were placed by means of a microsyringe on a slide coated with paraffin or on the adaxial surface of test leaves and mounted on a horizontal table illuminated from behind. Photographs were taken $1 \mathrm{~min}$ after the mounting of droplets
Table 1 Surfactants and their HLB values. ${ }^{\text {a }}$

\begin{tabular}{rlr}
\hline No. & \multicolumn{1}{c}{ Chemical description } & HLB \\
\hline 1 & POE lauryl ether & 10.5 \\
2 & POE lauryl ether & 12.1 \\
3 & POE oleyl ether & 10.1 \\
4 & POE oleyl ether & 13.6 \\
5 & POE oleyl ether & 16.2 \\
6 & POE cetyl ether & 10.7 \\
7 & POE cetyl ether & 14.2 \\
8 & POE stearyl ether & 9.4 \\
9 & POE stearyl ether & 13.9 \\
10 & POE octylphenyl ether & 13.5 \\
11 & POE nonylphenyl ether & 10.8 \\
12 & POE nonylphenyl ether & 14.5 \\
13 & POE nonylphenyl ether & 15.5 \\
14 & POE sorbitan monolaurate & 16.7 \\
15 & POE sorbitan monooleate & 15.0 \\
16 & POE sorbitan monopalmitate & 15.6 \\
17 & POE sorbitan monostearate & 14.9 \\
18 & POE sorbitan trioleate & 11.0 \\
19 & Sorbitan monolaurate & 8.6 \\
20 & POE sorbitol tetraoleate & 10.5 \\
21 & POE sorbitol tetraoleate & 11.8 \\
22 & POE sorbitol tetraoleate & 13.8 \\
23 & Polyethyleneglycol monolaurate & 13.7 \\
24 & Polyethyleneglycol monooleate & 11.6 \\
\hline & &
\end{tabular}

POE: polyoxyethylene.

a) Based on Kao technical information.

using a Nikon FE single lens reflex camera with extension rings. The negatives were projected and the droplet images were measured by a protractor.

\section{Retention Study}

In the retention experiment, methyl red dye (sodium salt of $p$-dimethylaminoazobenzene- $o$ carboxylic acid) was formulated into a $2 \%$ w/v aqueous solution with a surfactant. Five fresh excised leaves, or leaflets, were dipped into the dye solution for $2 \mathrm{~min}$. After the dye was allowed to dry, the leaves were washed three times with deionized water. The water used for washing the leaves was collected, transferred to a 200-ml volumetric flask and brought to volume. The dye concentration was assayed by a Hitachi 200-20 spectrophotometer at a wavelength of $440 \mathrm{~nm}$. After washing, the leaves were blotted with tissue paper and the leaf surface areas were determined with an AAC-100 automatic area meter 
(Hayashi Denkoh Co.). Retention values were expressed as $\mu \mathrm{g}$ dye $/ \mathrm{cm}^{2}$ of the leaf area.

\section{Statistical Analysis}

Correlation analysis between surface tension and contact angles or dye retention was performed on the data. Analysis of variance was also done and means from two or three replications were compared using Studentized range test, which was followed by the LSD test with a $5 \%$ level of significance, if necessary.

\section{RESULTS}

\section{Effect of Surfactants on Contact Angle}

As a factor of wettability, the contact angle on the adaxial surface of a rice leaf was measured and compared with that of the smooth surface of paraffin wax (Fig. 1). The contact angle of water droplet was higher on the rice leaf than on the paraffin $\left(137.2^{\circ}\right.$ and $102.2^{\circ}$, respectively). Surfactants were examined at $0.1 \% \mathrm{w} / \mathrm{v}$. On the paraffin, the relationship between the surface tension (ST) and the contact angle of droplets tended to be a positive linear correlation of contact angle on ST. While on the leaf, the relationship was different. On the basis of a contact angle of $110^{\circ}$, which is about the standard contact angle of water on paraffin, all surfactants examined were divided into two groups. Of six different classes of the surfactants (Table 1), the surfactants with contact angles below $110^{\circ}$ were from either POE alkyl ether or POE alkylphenyl ether. This group showed a highly positive correlation $(r=0.972 * *)$. In particular, the three surfactants, two POE lauryl ethers (HLB 10.5 and 12.1, respectively) and POE nonylphenyl ether (HLB 10.8), considerably decreased the contact angles.

\section{Reducing Surface Tension and Dye Reten- tion}

Effect of reducing ST on retention of methyl red dye was examined with rice, cabbage and soybean leaves using 11 surfactants showing different ST at a concentration of $0.3 \% \mathrm{w} / \mathrm{v}$ (Table 2). In rice and cabbage, the dye retention increased as the ST decreased and there was negative correlation between them, while in soybean, dye retention was not affected by reducing the ST and remained

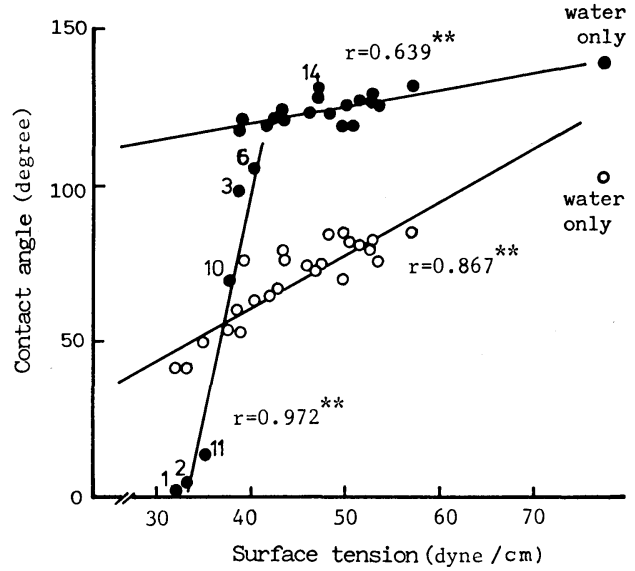

Fig. 1 Contact angles of nonionic surfactant solutions with different ST at $0.1 \% \mathrm{w} / \mathrm{v}$ on rice leaves (๑) and paraffin (O) .

Figures on circles show surfactant No.

** $p<0.01$.

Table 2 Relationship between surface tension (ST) and retention by plant leaves treated with dye solutions containing a surfactant at $0.3 \%$ $\mathrm{w} / \mathrm{v}$.

\begin{tabular}{rcccc}
\hline \multirow{2}{*}{$\begin{array}{c}\text { Sur- } \\
\text { factant } \\
\text { No. }\end{array}$} & $\begin{array}{c}\text { ST } \\
\text { dyne } /\end{array}$ & \multicolumn{3}{c}{ Dye retention $\left(\mu \mathrm{g} / \mathrm{cm}^{2}\right)$} \\
\cline { 3 - 5 } & $\mathrm{cm})$ & Rice & Cabbage & Soybean \\
\hline 11 & 34.7 & 43.10 & 43.74 & 37.40 \\
2 & 35.0 & 49.20 & 39.27 & 37.94 \\
3 & 36.6 & 54.19 & 47.74 & 44.79 \\
23 & 37.9 & 40.97 & 35.23 & 39.23 \\
10 & 40.7 & 53.68 & 38.23 & 44.48 \\
4 & 43.7 & 56.35 & 33.01 & 51.24 \\
14 & 45.6 & 32.10 & 10.24 & 50.12 \\
20 & 47.0 & 4.94 & 6.71 & 43.75 \\
8 & 47.9 & 7.02 & 13.74 & 52.67 \\
16 & 50.7 & 1.63 & 4.93 & 44.71 \\
5 & 52.0 & 0.53 & 3.87 & 44.26 \\
Water & 64.3 & 0.24 & 2.82 & 25.73 \\
& & & & \\
$r$ & - & $-0.805 * *$ & $-0.867 * *$ & -0.256 \\
\hline$* *$ & & &
\end{tabular}

relatively high even with the water control containing no surfactant.

Rice also showed similar trend when examined at the recommended field dilution using 8 commercial pesticide formulations (Fig. 2). ST and dye retention gave a highly negative correlation $\left(r=-0.914^{* *}\right)$. The IBP formula- 


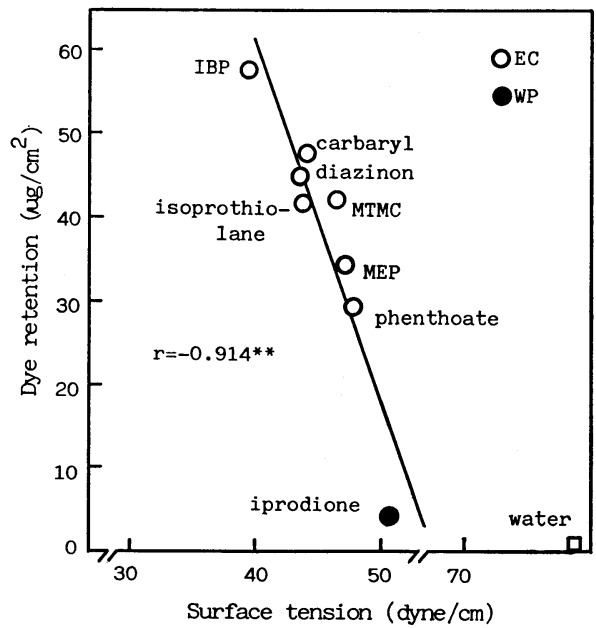

Fig. 2 Effect of the surface tension of pesticide formulations on the retention of methyl red dye by rice leaves.

** $p<0.01$.

tion retained the highest amount of dye of all and the iprodione formulation the least.

\section{Surfactant Concentrations and Wettability}

To study the effect of concentrations of surfactants on contact angles or dye retention, POE lauryl ether (HLB 12.1), POE nonylphenyl ether (HLB 14.5) and POE sorbitan monolaurate (HLB 16.7) were selected as representative wetting agents. The concentrations ranged from 0.001 to $1.0 \% \mathrm{w} / \mathrm{v}$. There was a marked difference in contact angles among three surfactants (Fig. 3). POE lauryl ether was most effective for reduction in contact angles. The extents appeared to be significantly different among three plant species at the rates of higher than $0.1 \% \mathrm{w} / \mathrm{v}$ at which rice showed the biggest reduction, and then cabbage and soybean the smallest. Such great reduction was not shown by two other surfactants.

In the dye retention experiments, however, all surfactants were effective for enhancing retention at their own optimum concentrations (Fig. 3). POE lauryl ether gave the maximum retention at $0.01 \%$, POE nonylphenyl ether at $0.1 \%$ and POE sorbitan monolaurate at $1.0 \% \mathrm{w} / \mathrm{v}$. There were no differences in optimum concentrations among plant species.
Considerable differences in retention among plant species became apparent when compared each surfactant at its optimum concentration. At every optimum concentration, the dye was most extensively retained on rice leaves.

It was clear that an addition of a surfactant was effective for enhancing retention. Particularly, on rice leaves, the highest amount of dye was retained, e.g., approximately 230-, 213- and 179-fold the water control by adding POE lauryl ether, POE nonylphenyl ether and POE sorbitan monolaurate, respectively. On cabbage leaves, the efficacy was also apparent, but not so high as seen on rice leaves. The additions on soybean leaves produced very little effects.

\section{Surfactant's $C M C$ and the Dye Retention}

The relationship between CMC and dye retention on rice leaves was studied at various concentrations of a surfactant, POE lauryl ether (Fig. 4). The $\mathrm{CMC}$ reached $0.01 \% \mathrm{w} / \mathrm{v}$ or more. At such $\mathrm{CMC}$, the rice leaves retained the highest amount of dye. Above the CMC, the retention reduced significantly with the concentration. The CMC values for $\mathrm{POE}$ nonylphenyl ether and POE sorbitan monolaurate were around 0.1 and 0.5 to $1.0 \% \mathrm{w} / \mathrm{v}$, respectively.

\section{DISCUSSION}

The assessment of leaf wettability in the rice plant by contact angles shows that rice leaves are highly water-repellent. The adaxial leaf surface displayed a higher contact angle of about $137^{\circ}$, and angles of such magnitude are considered by Holloway ${ }^{1)}$ to be largely a function of the epicuticular wax. The high water-repellency is also considered due to wax projections causing $130^{\circ}$ to $160^{\circ} .^{3)}$ This can be also supported by our electron microscope observation of the characteristic surface structure of rice leaves.

ST and contact angles examined with 24 nonionic surfactants showed a linear correlation on the smooth surface of paraffin. The contact angles are very variable on the rice leaf, indicating the involvement of other factors affecting wettability, such as cuticle roughness and trichomes ${ }^{1)}$ or physical and chemical properties of surfactant droplets. In 


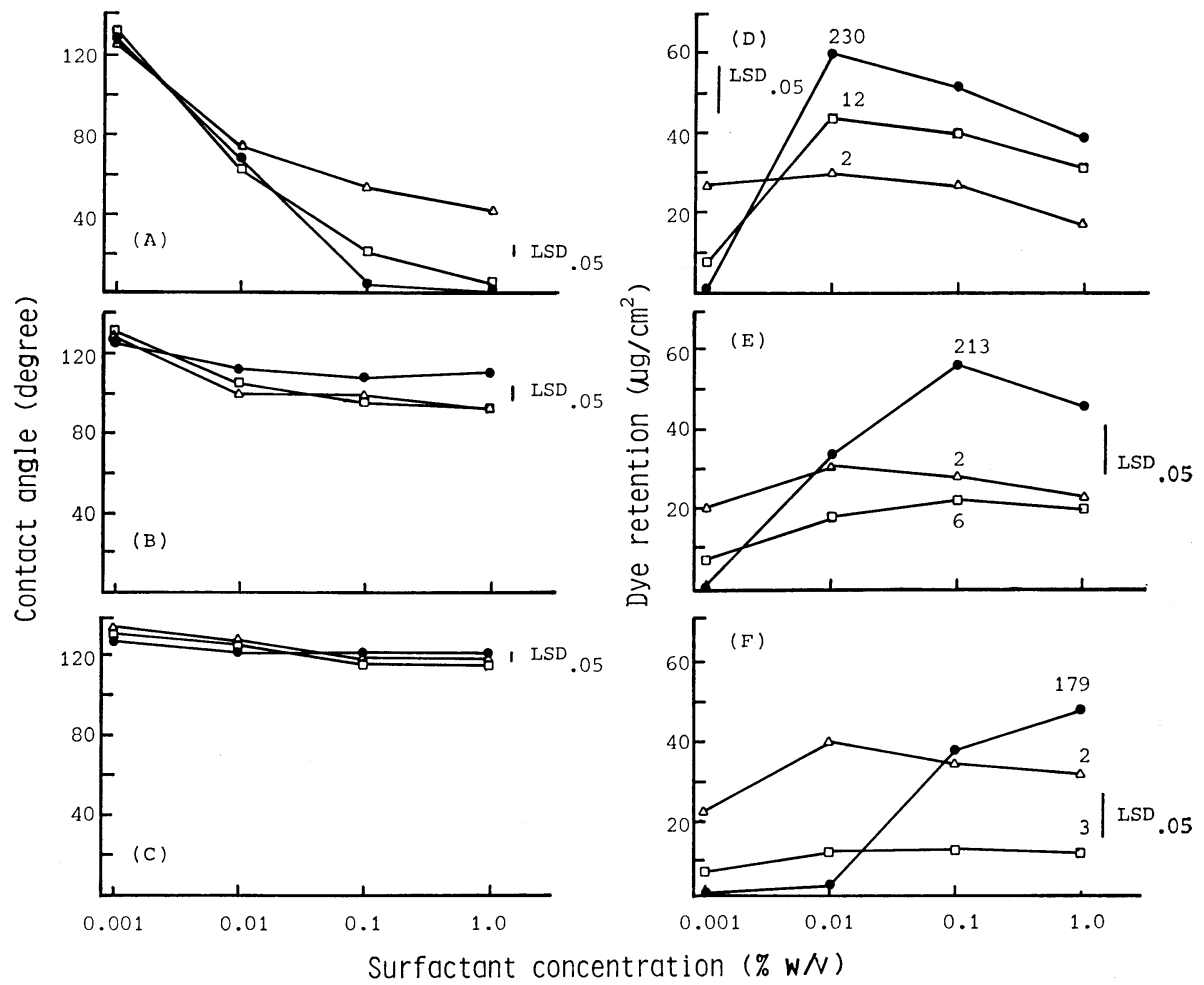

Fig. 3 Effects of surfactant concentrations on contact angles (A, B, C) and dye retention $(\mathrm{D}, \mathrm{E}, \mathrm{F})$ on the leaf surface ( rice, $\square$ cabbage, $\triangle$ soybean).

Surfactants: POE lauryl ether (A, D), POE nonylphenyl ether (B, E), POE sorbitan monolaurate $(\mathrm{C}, \mathrm{F})$. Figures on symbols show retention ratios to non-addition of surfactants. LSD: Studentized least significant difference at 5\% level.

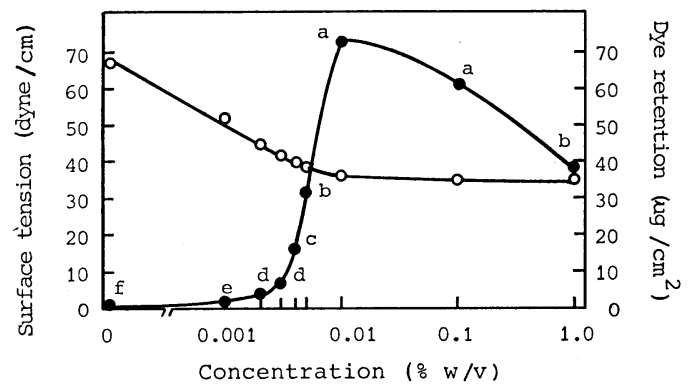

Fig. 4 Effect of concentrations of POE lauryl ether on surface tension $(\bigcirc)$ and dye retention (-) by rice leaves treated with dye solutions.

Closed circle's values followed by the same letter are not significantly different at 5\% level according to Studentized range test. the surfactant group with contact angles below $110^{\circ}$ on the leaf, three surfactants were markedly effective for the reduction in contact angles. They were two POE lauryl ethers and POE nonylphenyl ether and they appear to have a high affinity with the rice wax.

In the dye retention experiments using different surfactant species, surfactants with lower ST always showed higher retention, indicating that lowering ST increases retention. ST and dye retention give a negative correlation on rice and cabbage leaves. The retention of both species differ from that of soybean, in which no correlation was found between ST and retention.

Dye retention varies among plant species. ${ }^{4)}$ As discussed by Holly, ${ }^{2)}$ plant species can be divided into two groups; those whose retention is enhanced by lowering ST and those 
whose retention is decreased. In general, lowering ST reduces the retention volume of the species which are easily wetted and increases the retention of the species not readily wetted. Barley, pea and linseed, ${ }^{7)}$ and Chenopodium album ${ }^{6}$ ) belong to the difficult-towet type, while sunflower and Brassica alba, ${ }^{7}$ and apple, banana, bean and laurel, ${ }^{8)}$ and citrus, ${ }^{9)}$ are considered to be the easily-wetted type.

The relationship between ST and dye retention indicates that lowering ST enhances retention on water-repellent leaves such as rice and cabbage. Based on Holly's classification mentioned above, these two species belong to the difficult-to-wet type, while soybean with the hairy leaf surface is the type not affected by surfactants as well as radish and mustard species. $^{\text {.) }}$

Among the commercial pesticide formulations examined, the formulations with lower ST gave rice leaves higher dye retention. STretention correlation was also highly negative in rice leaves $\left(r=-0.914^{* *}\right)$. Yamamoto found that the addition of a wetting agent caused run-off of the spray retained on citrus leaves and suggested impracticability of wetting agents in citrus. $^{9)}$ This study, however, showed that rice is quite an opposite type compared to citrus with wettable leaves.

Studies of effects of surfactant concentrations on contact angles and dye retention also indicate difference in wettability among plant species. POE lauryl ether was most effective on reduction in contact angles, and the other two surfactants, POE nonylphenyl ether and POE sorbitan monolaurate, were less effective. This indicates that there may exist suitable surfactants for appropriate wettability on a plant species.

The dye retention experiments showed close interaction between aqueous surfactant solutions and the leaf surface. Each surfactant showed its own optimum concentration for dye retention. Surfactants with a lower HLB value tended to give maximum dye retention at a lower concentration; POE lauryl ether (HLB 12.1) at $0.01 \%$, POE nonylphenyl ether (HLB 14.5 ) at $0.1 \%$ and POE sorbitan monolaurate (HLB 16.7) at $1.0 \% \mathrm{w} / \mathrm{v}$.

These findings can be explained by the re- lationship between $\mathrm{CMC}$ and dye retention. The CMC of POE lauryl ether was around $0.01 \%$, at which rice leaves retained the highest amount of dye. CMC values of POE nonylphenyl ether and POE sorbitan monolaurate were near $0.1 \%$ and 0.5 to $1.0 \% \mathrm{w} / \mathrm{v}$, respectively. Thus, both surfactants did show the highest retention at their own CMC. These surfactants all exhibited the highest retention at the same concentration in every test plant, indicating no difference in optimum concentrations of surfactants for plant species.

However, every surfactant, at its optimum concentration or CMC, produced a significant difference in retention among test plant species.

The data suggest that lowering surface tension is very effective for enhancing dye retention on plant species, particularly the ones with low wettability like rice plants. Although enhancement of retention by leaves was discussed here as an important factor of surfactant effectiveness, other factors such as absorption and movement remain to be clarified.

\section{ACKNOWLEDGMENTS}

The authors wish to thank Kao Corporation for providing a number of surfactants. Appreciation is also expressed to Prof. T. Nakamura of Shimane University for numerous helpful suggestions.

\section{REFERENCES}

1) P. J. Holloway: Pestic. Sci. 1, 156 (1970)

2) K. Holly: "Herbicides," ed. by L. J. Audus, Vol. II, Academic Press, London, p. 249, 1976

3) H. M. Hull, D. G. Davis \& G. E. Stolzenberg: "Adjuvants for Herbicides," Weed Science Society of America, Champaign, p. 26, 1982

4) D. R. Johnstone: "Pesticide formulations," ed. by W. Van Valkenburn, Marcel Dekker, Inc., New York, p. 343, 1973

5) C. E. Blackman, R. S. Bruce \& K. Holly: J. Exp. Bot. 9, 175 (1958)

6) F. E. Taylor, L. G. Davies \& A. H. Cobb: Ann. Appl. Biol. 98, 471 (1981)

7) W. A. Taylor \& G. B. Shaw: Pestic. Sci. 14, 659 (1983)

8) W. D. E. Thomas \& L. Potter: Proc. 4th Int. Congr. Surf. Act. Subst., Vol. 3, Brussels, Gordon and Breach, New York, p. 475, 1967

9) S. Yamamoto: Proc. 4th Symp. Pestic. Form. Appl., Pestic. Sci. Soc. Jpn., p. 27, 1984 (in Japanese) 
要約

\section{イネ葉の濡れ性に及ばす界面活性剤の影響}

門田源一，松中昭一

非イオン系界面活性郕の水溶液を用いて，イネ葉の濡 れに及ぼす影響を接触角および色素付着性の点から，キ ヤベツおよびダイズと比較検討した，その結果，イネ葉 の濡れ性は非常に低いことが判明した．濡れの特性は色 素付着性の検討によりいっそう明らかとなり，濡れ性が 低い植物では, 表面張力と色素付着量との間に負の相関 が認められた。 また，界面活性片の濃度を0.01 1.0\% (w/v)の範囲内で検討した結果, 接触角の低下には POE lauryl ether が最も有効に作用したが，色素付着性にお いては界面活性剤間で異なる結果が得られた。すなわ ち，最大付着量を示す濃度は界面活性剂の種類により異 なった (POE lauryl ether $0.01 \%, \mathrm{POE}$ nonylphenyl ether $0.1 \%$, POE sorbitan monolaurate $1.0 \%)$ 。 また, POE lauryl etherに扔いて, 最大付着量を示す濃度はその $\mathrm{CMC}$ 值と一致し, 濡れ性の植物種間差もこの濃度付近 で有意に現われる傾向にあった。色素付着性に対する界 面活性鼡の影響はイネに扔いて顕著で, 無添加区に比較 すると著しい付着性の増大が認められた。 